\title{
Does Practice of Learning Skills and Attitudes Impact to Intention to Be A Teacher
}

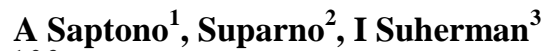 \\ 1,2,3 UniversitasNegeri Jakarta, Rawamangun 13120, Indonesia
}

\begin{abstract}
This study aims to determine whether there is an influence between Attitudes to Teacher Proffessions and Students Perception of Teaching Skill Practice (PKM) on intention to be teacher learning in students of Economic Education Program Faculty of Economics UnniversitasNegeri Jakarta Class of 2013. This research method uses survey method. The population in this study were all students majoring in economic education in 2013 totaling 76 students. The sampling technique using total sampling technique or better known as census. Data analysis techniques using SPSS 22.0. Results obtained the equation $\mathrm{Y}=0.44 \mathrm{X} 1+$ $0.39 \mathrm{X} 2+28,73 \varepsilon 1$. The Rsquare value is 0,656 which means that economic learning outcomes can be explained by Attitudes to Teacher Proffessions and Students Perception of Teaching Skill Practice (PKM) are able to expalin as much as 65,6\% variation in intention to be teachers, while the remaining $34,4 \%$ is influenced by other variables not examined.
\end{abstract}

Keywords.Attitudes Teacher Profession, Students' Perceptions of Teaching Skills Practices (PKM), Teaching Skills Practices (PKM), Intention to be a Teachers.

\section{INTRODUCTION}

Education is a process that is taken by someone to gain knowledge, insight, and develop attitudes and skills according to the needs of the community. Regarding the needs of education and technology as well as the development of the global community, education is required to prepare planned and systemic learners to face current and future challenges. In order to achieve these goals there needs to be an increase in the quality of education. The main quality of education is largely determined by the teaching and learning process. The teaching and learning process involves students as learning parties and teachers as instructors or educators.

The teacher is an educator whose job is to educate and educate the nation's next generation. Law No. 14 of 2005 concerning Teachers and Lecturers (Article 1 paragraph 1) states that "Teachers are professional educators with the main task of educating, teaching, guiding, directing, training, evaluating, and evaluating students in early childhood education. formal, basic and secondary education ". This means that in the educational interaction, the teacher has a role to organize the process and is responsible for the success of learning for students, so that the educator's goals can be achieved.

Jakarta State University (FE UNJ) is one of the LPTK which aims to produce competent, qualified and professional educators. One of the UNJ FE Economics Education Study Programs aims to produce competent, qualified and professional economic teacher candidates. Students are equipped with mastery of knowledge in the field of teacher training and technological discipline of economics.

Copyright $($ C 2019, the Authors. Published by Redwhite Press.

Page $\mid 168$

This is an open access article under the CC BY-NC license

(http://creativecommons.org/licenses/by-nc/4.0). 
This is so that after students graduate from college, students have a wider opportunity to choose the job they want.

One of the study programs at UNJ is the Cooperative Economic Education Study Program. The Study Program has the aim of preparing prospective educators in the economic field. During the education period, students are equipped with mastery of the science of the field of the education profession and the technology of disciplinary economics, so that after graduating from college, students can channel their intention in work and students are expected to be intentioned in being able to work as educators (teachers).

The results of the interviews showed that the phenomenon of intention in the teaching profession was $40 \%$ of economic education students who were not intentioned in becoming teachers. Student intention is largely influenced by several factors, both internal and external, such as student perceptions of the Practice of Teaching Skills (PKM) and student attitudes towards the teaching profession at this time. Richardson and Watt stated that someone's intention in choosing a career is influenced by several factors including the level of education and one's perception of the career to be chosen. Perception is the interpretation, judgment, assumption or opinion of someone about an object. Considering that everyone has different attitudes and perceptions in their lives, this is normal.

Based on observations in the field, the incompatibility of career choices of the Economic Education Study Program graduates of the State University of Jakarta with its mission and objectives revealed the tracer study data of 2017 Economic Education graduates showing that the majority, Economic Education graduates did not choose careers as educators or teachers and education staff. This can be seen from the results of the Tracer Study of Economic Education at the Jakarta State University.

The number of UNJ graduate students in Economic Education study programs who work as teachers is only 25 people or $9.2 \%$ of the 271 alumni of the Economic Education study program, the remaining 246 people or $91 \%$ work in banks, private employees, government and some who are unemployed due to contract expiration or looking for work.

The intention of students to become teachers is influenced by several factors, one of the factors suspected of influencing it is the student's own perception of the Practice of Teaching Skills (PKM). PKM at school is one of the activities that must be followed by every student in the education department. Where in its implementation students are really confronted in the real class. Students are required to be able to practice all theories obtained from previous semesters in accordance with predetermined requirements so that they gain experience and skills about the implementation of education and teaching in schools. Here students can really feel how to be a real teacher.

However, in its implementation there were still various obstacles that made the experience gained when following the Teaching Skills Practice (PKM) each student got a different impression so as to form different perceptions. It is expected that after completing the Teaching Skills Practice (PKM), students can find that they are capable or not to work as a teacher through their teaching skills. The perception that someone gets in a profession will influence someone's intention in choosing a career. So that it is expected to be able to equip students and can increase students' intention in becoming teachers.

\section{Intentionto be a Teachers}

Intention means tendency and high enthusiasm for something. Intention is an important component in life in general and in education in particular. Every individual has their own intentions, intention arises because of obtaining information or knowledge about a job, object or situation.According to MahfudinShalahudin that "Intention is attention that contains elements of feeling that cause someone to act actively in a job and can be a cause of an activity".

Kurt Singer said that "Intention is not something someone just has, but is something that is developed". This explains that intention can arise self-encouragement and also encouragement from the outside, because often involved in an activity can cause intention. This is in accordance with what was stated by HC Whiterington that "Individual intention can arise in an object that is related to its needs". So basically someone's intentions can arise because of their life needs, such as physiological 
needs, the need for security, social needs, the need for appreciation, and the need to realize themselves. Intention is one of the human psychological factors that is very important for progress and success in a person. Intention plays an important role in one's life and has a big impact on attitudes and behavior. Dalyono explained that intention can arise because of the attraction from the outside and also from the heart. Great intention in something is a big capital that means to reach / get the object or destination that intention it. Someone who is intentioned in a particular job will get better results than those who are not intentioned.

The intention in becoming a teacher means concentrating one's thoughts, feelings, willingness, or attention towards the teaching profession. The intention in becoming a teacher can arise because of the knowledge and information about the profession of being a teacher accompanied by a sense of pleasure and intention in the teaching profession so that there arises a desire and desire to become a teacher. So the intention in being a teacher can be measured through components such as the presence of someone's awareness of something, having an attitude to make desired decisions, the presence of greater attention, an intention in education and a desire to become a teacher.

So it can be concluded that the intention in being a teacher is an intention in someone who raises awareness, attitudes, intentions, attention, more desire to understand knowing and studying the teaching profession and ultimately has the desire to work as a teacher.

\section{Practice of Teaching Skills (PKM)}

Practice is the actual implementation of what is called in theory. Practice is a way of doing it in the real situation what is stated in the theory. From the above definition we can see that practice is an implementation of the theory in real conditions.

The Jakarta State University (UNJ) as an LPTK (Educational Personnel Education Institution) has a very important role in producing graduates in the education field who have professional teacher competencies. Therefore, UNJ as an LPTK made a major commitment to improve the quality of its graduates. To achieve this quality, a program is needed that provides development in the form of professional training for students. Professional training is called the Field Experience Program (PPL), which has now been renamed the subject of Teaching Skills Practice.

According to the Jakarta State University (UNJ) Teaching Skills Handbook (PKM), courses in the S1 study program for the academic year 2010/2011 were renamed the subject of Teaching Skills (PKM) courses. Teaching Skills Practices (PKM) is one of the compulsory subjects for educational students at the Educational Personnel Education Institution (LPTK). This course takes the form of a practical course with a weight of 2 credits and is done as a prerequisite for participating in PPL-PPG.

Teaching Skills Practices (PKM) is a series of activities that have been jointly prepared and integrated which consist of planning, organizing, implementing, monitoring, controlling and fostering all resources so that the objectives of the learning experience in the field can be achieved. Teaching Skills Practices (PKM) are courses that are oriented towards efforts to develop and improve teaching skills, especially learning skills in front of the class. The Practice of Teaching Activities is an effort to help prospective teachers to practice 8 basic learning skills and the achievement of 4 competencies must be possessed by the teacher.

Law No. 14 of 2005 concerning Teachers and Lecturers, in Chapter IV article 10 and in Government Regulation No.19 of 2005 concerning National Standards of Education, in Chapter VI article 3 has emphasized the competence of educators and education personnel. These competencies include: pedagogic competence, personality competence, professional competence, and social competence.

The General Purpose of Teaching Skills Practices (PKM) is to train students to have the ability to apply various kinds of knowledge, attitudes, and skills learned in real situations, both for teaching activities and non-teaching tasks in order to form prospective teachers and education staff who professional.

The Practice of Teaching Skills (PKM) also aims to equip students to have the ability of educational professionals. As a professional education staff, UNJ graduates in the education field 
must have a set of competencies needed by a professional teacher who can implement various educational programs, both at school and outside the school.

\section{Attitudes towards the Professionals of Teachers}

Attitude is an abstract concept of understanding human behavior. Someone will easily understand the behavior of other people by first knowing the attitude or background of the formation of attitudes towards the person. Many social psychologists put forward various formulas for understanding attitudes. Cardino said that attitude as "Attitude Predisposition to Response to Social Objects, in interaction with other situations and variables, guides, and direct the overt behavior of the individuals". Attitude is a system of positive or negative judgment, emotional feelings, and a tendency towards pro or contra actions that favor a social object. Trow as quoted by Djaali in his book Educational Psychology says that attitude is a mental or emotional readiness in some types of actions in the right situation. This emphasizes the mental and / or emotional readiness of a person towards an object. Meanwhile Gordon Allport, gave the concept of attitude as a kind of readiness to react to an object in a certain way. Readiness in the concept, as a potential tendency to react when someone is faced with a stimulus that requires a response. Together with this can be said attitudes as behavioral patterns or anticipatory readiness to adjust to social situations, or it can be said attitude is a response to social stimuli that have been conditioned.

Harlen argues that attitude is readiness, willingness or tendency of a person to act in dealing with an object or situation. In general, a person's attitude towards an object can be classified as a positive attitude or a negative attitude. In a positive attitude, the tendency of action is to approach, like, and expect objects. Whereas in negative attitudes there is a tendency to avoid, dislike and even hate objects. From the definitions of attitudes that have been formulated by the experts above, there are similarities, each of which includes words of tendency, willingness, and readiness. Based on this, what is meant by attitude is readiness, tendency, willingness to react or act on an object.

Etymologically, the profession comes from the English term namely profession or latin, profecus, which means recognizing, acknowledging, declaring capable, or expert in carrying out certain jobs. Profession can be interpreted as a job that requires higher education for the perpetrators who emphasize mental work, not manual work. This means that a job or position called a profession cannot be held by any person, but requires preparation through special education and training. The word profession identi with the word expertise. In line with this Volmer argues that the profession as a specialization of intellectual position obtained through study and training, aims to create skills, highvalue jobs, so that the skills and jobs are respected, loved by others, and can do work in accordance with the code of ethics and get rewards in the form of payments, wages, salaries.

The teacher is a profession or teacher's expertise position obtained through special education or training, to fulfill certain requirements. According to Ametembun, "Broadly speaking the teaching profession includes roles and tasks that are in certain working conditions. The task is to guide, teach, and administer the class ". Being a teacher is not easy because the responsibilities are quite heavy.

Based on the description above, according to researchers the understanding of attitudes towards the teaching profession is readiness, tendency, willingness, to react or act towards educational activities such as educating, teaching, or guiding students, which are based on a commitment to work as a teacher.

\section{METHOD}

The method used in this study is a survey method with a correlation approach, the approach used is a correlational approach to determine how much influence attitudes toward the teaching profession $\left(\mathrm{X}_{1}\right)$ and student perceptions of the practice of teaching skills $\left(\mathrm{X}_{2}\right)$ as independent variables or variables free which affects the intention in becoming a teacher $(\mathrm{Y})$ as a dependent variable.

Population is a generalization area consisting of objects or subjects that have certain quantities or characteristics determined by researchers to be studied and conclusions drawn. Whereas the reachable population is a student of 2013, the concentration of Cooperative Economic Education is 76 students consisting of two classes. Data analysis is done by parameter estimation of the regression 
model to be used. From the regression equation obtained, testing is done with the regression analysis so that the equation obtained approaches the actual situation.

\section{RESULTS AND DISCUSSION}

This study consisted of two independent variables, namely attitudes toward the teaching profession $\left(\mathrm{X}_{1}\right)$ and student perceptions of Teaching Skills Practices (PKM) $\mathrm{X}_{2}$, and one dependent variable was the intention in becoming a teacher (Y). The Influence of Attitudes Towards the Professionals of Teachers Against the Intention in Becoming Teachers of

\section{Influence on Student Perceptions of Teaching Skills Practices (PKM) Against the Intention in Becoming Teachers}

Based on the results of multiple regression analysis, the influence of students' perceptions of teaching skills practices towards intention in becoming teachers through t-test was obtained $t_{\text {count }}(5,591)>t_{\text {table }}(1,992)$, which means that students' perceptions of the practice of teaching skills partially have a positive and significant effect on the intention in becoming a teacher. This means that if students 'perceptions of PKM increase (good), then the intention in becoming a teacher will increase and vice versa, if students' perceptions of PKM decline (bad) then the intention in becoming a teacher in students will also decrease.

The results of this study are in line with the results of previous studies conducted by TutiOktaviani and AgungYulianto with the title "The Influence of Field Experience Practices on Accounting Profession Teachers and Teacher Welfare Against the Intention of Becoming Teachers in Accounting Teacher Professions (Case Study of Accounting Education Study Program Semarang "shows that the significant effect of PPL on the intention in becoming a teacher. The PPL variable influences the intention in becoming a teacher by $10.11 \%$.

The results of this study are in line with the results of previous research conducted by IntanPrawidaSofiyana with the title" Influence of Influence on Field Experience Against Intention in Becoming Teachers on UNY Music Art Education Students "showed that the significant influence of PPL on teacher intention. PPL variables affected the intention in becoming a teacher by $69.4 \%$.

Based on the things described above, it is clear that students' perceptions of the practice of teaching skills $\mathrm{r}(\mathrm{PKM})$ has a positive effect on the intention in being a teacher which is in accordance with the results of this study and also supports the theory and strengthens the results of relevant research.

\section{The Influence of Attitudes Toward the Professionals of Teachers and Student Perceptions of Teaching Skills Practices (PKM) on Intention in Becoming Teachers}

Based on the results of multiple regression analysis, the influence of attitudes toward the teaching profession and student perceptions of megajar skills (PKM) on intention in becoming a teacher through $F$ test was obtained $F_{\text {count }}(69,589)>F_{\text {table }}(3,12)$ which means that attitudes toward the teaching profession and student perceptions about the practice of teaching skills (PKM) simultaneously have a positive and significant effect on the intention in becoming a teacher.

Percentage of attitudinal contribution to the teaching profession and student perceptions of the practice of teaching skills (PKM) towards the intention of becoming a teacher obtained a coefficient of determination of 0.656 which means attitude variables towards the teaching profession and student perceptions of teaching skills practices (PKM) were able to explain $65.6 \%$ variation intention in becoming a teacher, while the remaining $34.4 \%$ is influenced by other factors not examined.

The relationship between attitudes toward the profession of teachers and students' perceptions about the practice of teaching skills (PKM) to the intention to be a teacher in this study had a regression equation $\mathrm{Y}=28.73+0,44 \mathrm{X}_{1}+0,39 \mathrm{X}_{2}$. This regression equation means that the attitude towards the teaching profession and the perception of students about the practice of teaching skills (PKM) is 0 , then the intention in being a teacher is 28.729 rounded to 28.73 . The coefficient value (b1) is 0.44 which means that if the students' perceptions of the practice of teaching skills are fixed and attitudes toward the teaching profession experience a 1 point increase, the intention in becoming a teacher will increase by 0.11 - assuming other independent variables are fixed. Coefficient value (b2) of 0.90 means that if the social interaction value is fixed and the effectiveness of learning media has 
increased by 1 point, then student learning achievement will increase by 0.90 assuming another independent variable is fixed value.

\section{CONCLUSIONS}

Conclusions This of this research has succeeded in giving conclusions empirically and proving that the hypotheses stated earlier are correct. The conclusion is in the form of:

1. There is a positive and significant influence between attitudes towards the teaching profession towards the intention in becoming a teacher. If the attitude towards the teaching profession is good or positive, then the intention in being a teacher will increase, and vice versa if the attitude towards the teaching profession is bad or negative, then the intention in becoming a teacher in students will decrease.

2. There is a positive and significant influence between students' perceptions of the Practice of Teaching Skill (PKM) on the intention in becoming a teacher. If students 'perceptions of Teaching Skills Practices (PKM) are good or positive, then the intention in becoming a teacher in students will also increase and vice versa if the students' perceptions of Teaching Skills Practices (PKM) are bad or negative, then the intention in becoming a teacher in students will decrease.

3. There is a positive and significant influence between attitudes towards the teaching profession and students' perceptions of Teaching Skills Practices (PKM) on the intention in becoming a teacher. This means, the better the attitude towards the teaching profession and the perceptions of students about Teaching Skills Practices (PKM), the higher the intention in becoming a teacher for students, and vice versa if attitudes towards the teaching profession and student perceptions of Teaching Skills Practices (PKM) are getting worse, then the intention in becoming a teacher in students is getting lower.

\section{REFERENCES}

Abror, Abdul Rachman. Educational Psychology. Yogyakarta: PT. Taira Wakana. 1993

Aprylian, LA Factors Affecting Accounting Students in Career Selection Becoming a Public

Accountant, undergraduate thesis, Semarang: Undergraduate Program of the Faculty of

Economics, Diponegoro University. 2011. EEAJ. No.3, Vol.3.

Arikunto, Suharsimi. Research Procedure A Practice Approach. Jakarta: PT. Rineka Cipta. 2007.

Research Management, Jakarta: Rineka Cipta. 2007.

Azwar, Saifuddin. Human Attitudes Theory and Measurement. Yogyakarta: Learning Library. 2012.

Djaali. Educational Psychology. Jakarta: Bumi Aksara: 2007.

Gibson., Ivancevich, Donnely. Organization and Management, behavior, Process Structure. Jakarta: Erlangga. 1990.

Hamalik, Oemar. Teacher Education Based on Competency Approach. Jakarta: PT Bumi Aksara. 2004.

Imam, Ghozali. Econometrics. Semarang: Diponegoro State University Publishing Agency. 2009.

Hurlock. Child Development Volume 2. Jakarta: Erlangga Publisher. 2010.

Jenifer, Mahon and Jill Packman. "Focused Career Choices: How Teacher Educators Can Assist Students with Purposeful Career Decision Making throughout a Teacher Education Program". (Teacher Education Quarterly Spring University of Nevada: 2011)

Katrin Saks, Reet Soosaar, Helen Ilves. "The Student's Perceptions and Attitudes To Teaching Profession, the Case of Estonia". University of Tartu Pärnu College. The European Preoceedings of Social \& Behavioral Sciences EpSBS. 2016. eISSN 23571330.

Kommarudin. Dictionary of the term Scientific Writing. Jakarta: PT. Earth Literacy. 2006. 
Linda L. Davidoff. Interpretation of Mari Jumiarti. An Introduction to Psychology. Jakarta: Erlangga. 1992.

Priyatno, Duwi. SPSS Colleration and Regression Analysis. Yogyakarta: Gava Media. 2009.

Shah, Muhibbin. Educational Psychology with a New Approach. Bandung: PT. Teenager Rosdakarya. 2008.

FE UNJ Alumni Alumni Tracer Study. 2015 / 2016-2016 / 2017

Law of the Republic of Indonesia Number20 of 2003 concerning the Education System.

State University of Jakarta. Guidelines for Implementing Field Experience Programs (PPL). 2012.

Walgito, Bimo. Introduction to General Psychology. Yogyakarta: Andi Offset. 2004. 